\title{
Knowledge of occupational diseases and immunization among healthcare students
}

\section{Conhecimento de doenças ocupacionais e imunização entre estudantes de saúde}

\begin{abstract}
Purpose: To investigate the knowledge and practices of immunization against occupational diseases and its associated factors among health students.

Methods: An exploratory cross-sectional study was carried out with a random sample of 275 graduate students from the Schools of Dentistry, Physiotherapy, Pharmacy, Psychology and Nursing. During data collection we carried out individual interviews on issues related to immunization coverage, diseases and occupational accidents and sociodemographic variables. The statistical tests used were the Pearson's chi-square and Fisher's exact tests $(\alpha=0.05)$.

Results: Most students considered influenza (65.5\%) and hepatitis B (58.5\%) occupational diseases. Almost $30 \%$ of the students reported having attended to patients with infectious diseases, especially AIDS. Contact with body fluids or accidental exposure was reported by $12.7 \%$ being $34.3 \%$ by accident with drills; $88.2 \%$ of the students had incomplete immunization coverage due to lack of time in most cases $(27 \%)$. None of the variables was significantly associated with vaccination coverage.

Conclusion: The students' knowledge of occupational diseases and vaccination coverage was poor, which reflects the need for motivational policies through activities for clarification and expansion of vaccination coverage.
\end{abstract}

Key words: Immunization coverage; healthcare students; infection control; occupational risks

\section{Resumo}

Objetivo: Investigar o conhecimento e as práticas de imunização contra doenças ocupacionais e fatores associados entre estudantes de saúde.

Metodologia: Foi realizado um estudo transversal exploratório, com amostra probabilística composta por 275 universitários dos Cursos de Odontologia, Fisioterapia, Farmácia, Psicologia e Enfermagem. Na coleta de dados utilizou-se entrevista individual com questões relacionadas à cobertura vacinal, ao conhecimento de doenças, a acidentes ocupacionais e fatores sociodemográficos. Os dados foram analisados por testes Qui-Quadrado de Pearson e o Exato de Fisher ( $\alpha=5 \%$ ).

Resultados: A maioria dos estudantes considerou influenza (65,5\%) e hepatite B $(58,5 \%)$ como doenças ocupacionais. Quase 30\% relataram já ter atendido pacientes com doenças infectocontagiosas, principalmente AIDS (7\%). O contato com fluidos orgânicos ou a exposição acidental foi relatada por $12,7 \%$ dos entrevistados, através de acidente com instrumento perfuro-cortante $(34,3 \%) ; 88,2 \%$ dos acadêmicos apresentaram cobertura vacinal incompleta, sendo a falta de tempo o motivo mais citado (27\%). Nenhuma variável mostrou associação significativa com a cobertura vacinal.

Conclusão: $O$ conhecimento dos acadêmicos sobre doenças ocupacionais e a cobertura vacinal foram deficientes, refletindo a necessidade de políticas motivacionais, através de atividades de esclarecimento e ampliação da cobertura vacinal.

Palavras-chave: Cobertura vacinal; estudantes de ciências da saúde; controle de infecção; risco ocupacional

\author{
Ana Flávia Granville-Garcia a \\ Eveline Sales Rocha a \\ Raulison Vieira de Sousa a \\ Veruska Medeiros Martins a \\ Andreza C. de L. Targino Massoni b \\ Saul Martins Paiva ${ }^{\mathrm{c}}$
}

- Faculty of Dentistry, State University of Paraíba, Campina Grande, PB, Brazil

b Faculty Dentistry, Integrated Faculty of Patos, Patos, PB, Brazil

c Faculty of Dentistry, Federal University of Minas Gerais, Belo Horizonte, MG, Brazil

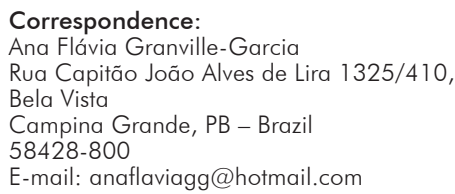

Conflict of Interest Statement: The authors state that there are no financial and personal conflicts of interest that could have inappropriately influenced their work.

Copyright: (C) 2011 Granville-Garcia et al.; licensee EDIPUCRS. This is an Open Access article distributed under the terms of the Creative Commons AttributionNoncommercial-No Derivative Works 3.0 Unported License. 


\section{Introduction}

Health professionals are a group of particular concern in relation to infectious diseases, since during their work activities they are usually exposed to risks posed by biological agents due to contact with body fluids potentially contaminated with a variety of pathogens (1). Among the measures to prevent some infections in the workplace are included the immunization and monitoring of vaccination status of professionals, considered essential in infection control programs for this group (2).

In Brazil, the Norm of the Ministry of Labour (NR 32) determines the mandatory vaccination of health (3). However, the National Immunization Program (NIP) does not present a specific protocol of vaccination coverage for this group of workers. In general the vaccines recommended by this program include: hepatitis B, measles, rubella, diphtheria and tetanus (4).

The inadequate immunization status of health professionals is a serious public health problem (5), not only by the possibility of contamination of their peers but also of patients (6). Vaccination is performed for free in health clinics; nevertheless, vaccine coverage in Brazil is far from achieving the $100 \%$ vaccination goal (3). This finding may be attributed to lack of knowledge by health professionals, lack of availability of these vaccines in the health services, as well as by the little importance given to this specific protection procedure (5).

There is a growing concern that health professionals enter the job market in a disorderly way, usually without biosecurity training and without checking their immunization status (5). In this sense, it is necessary to know the individual immunity for professionals and students in this area in order to identify and correct gaps in coverage for immunopreventable diseases. In relation to students, it is recommended that corrective measures are taught while they are still in grad school, before contact with patients, to avoid exposure to unnecessary risks (2). Additionally, the awareness of occupational diseases, the risk of transmission and the need for immunization should be present from the period of academic training. From this perspective, Higher Education Institutions have a great responsibility to prepare students for safe clinical practice.

Thus, this study aims to evaluate the knowledge and practices for immunization against infectious diseases among students in the health field of the State University of Paraíba, Brazil.

\section{Methods}

This study was approved by the Human Research Ethics Committee of the State University of Paraíba (0415.0.133.000-09 Protocol), according to Resolution 196/96 of the National Health Council. Moreover, when students agreed to participate in the study, they signed the informed consent form.
A cross-sectional and exploratory study was carried out, with an inductive approach and descriptive-analytical statistical procedure. A total of 275 students attending courses from the State University of Paraiba, Campina Grande, Brazil, in the Health field (Dentistry, Physiotherapy, Pharmacy, Nursing and Psychology) participated in the study. Campina Grande is the second most important city in the state of Paraiba. This city is situated $130 \mathrm{~km}$ from state capital, in the area, between the coast and hinterland in the Eastern Highlands of Borborema. The city area covers $620.6 \mathrm{~km}^{2}$ and has about 371,060 inhabitants (population density: 612 inhabitants $/ \mathrm{km}^{2}$ ). It is considered the educational center of the interior of Paraiba (7). The number of students was obtained directly from the coordination of each course, totaling 1,548 students, of which 668 were enrolled in the professional stage (clinical care), representing the population of interest for this study. The sample design was probabilistic with proportional split to the number of students in each course. The sample size calculation considered a $95 \%$ confidence level with a 5\% margin of error and expected ratio equal to $50 \%$. Thus, the minimum sample size was 245 students and $20 \%$ increase was added to this value due to possible losses, yielding a sample size of 294 students.

Data collection was randomly performed, through individual interviews during the period between September to December 2009. The sample was simple random, with the list of students obtained from the courses' coordination. On the form were included questions related to sociodemographic factors, knowledge of occupational diseases, occupational infections and vaccination table status (vaccination coverage) of students, based on the calendar for health professionals recommended by the Ministry of Health (6) and the reasons for not being vaccinated. It was considered to have full vaccination coverage of those who had reported having been immunized (full dosage) against: hepatitis B - three intramuscularly $1 \mathrm{~mL}$ doses, with 30 days interval from the 1 st to the 2 nd dose and 180 days interval from the $1 \mathrm{st}$ to the 3 rd dose. Dual viral (measles and rubella) - single subcutaneously $0.5 \mathrm{~mL}$ dose. Influenza - one subcutaneously $0.5 \mathrm{ml}$ dose, annually. dT - three intramuscularly $0.5 \mathrm{~mL}$ doses at 60 days intervals. Responses were recorded on a specific form, ensuring the confidentiality of all information and not exceeding the time of ten minutes per respondent. The interviews were conducted by two researchers, appropriately trained at the University itself, aimed at not interfering with the daily activities of students.

The reliability of responses was tested by the "face" validation method in $10 \%$ of subjects in the research. By this method, the researcher asks the research subjects for an explanation, in their own words, of their understanding about each question (8).

From the data analyses were obtained the uni- and bivariate absolute and percent distributions and the statistical measures: mean, standard deviation, coefficient of variation, minimum and maximum values of the age variable (descriptive statistics) and used the Pearson's chisquare and Fisher's exact tests when the conditions for using 
the chi-square test were not verified (inferential statistical techniques). The level of significance used in statistical tests was $5.0 \%(P<0.05)$. The software used to obtain the statistical calculations was SAS (Statistical Analysis System), version 12.0.

\section{Results}

A total of 275 students were interviewed and 19 refused to participate in the study. The age of respondents ranged from 18 to 57 years old (mean: 23.22 years old, median: 23 years old, standard deviation: 4.21 years old; coefficient of variation: $18.13 \%$ ).

Table 1 shows that the majority of participants were $22-23$ years old (36\%), female (65.8\%), single $(92.4 \%)$, did not work $(87.6 \%)$ and did not live with parents $(55.6 \%)$. The course with greater frequency of participation was Physiotherapy (34.9\%).

Table 1. Distribution of respondents according to demographic and occupational charateristics.

\begin{tabular}{|c|c|c|}
\hline Variable & $\mathrm{n}$ & $\%$ \\
\hline \multicolumn{3}{|l|}{ Age range } \\
\hline 18 to 21 years & 89 & 32.4 \\
\hline 22 to 23 years & 99 & 36.0 \\
\hline 24 to 57 years & 87 & 31.6 \\
\hline \multicolumn{3}{|l|}{ Sex } \\
\hline Male & 94 & 34.2 \\
\hline Female & 181 & 65.8 \\
\hline \multicolumn{3}{|l|}{ Marital status } \\
\hline Single & 254 & 92.4 \\
\hline Married & 21 & 7.6 \\
\hline \multicolumn{3}{|l|}{ Occupational status } \\
\hline Working (out) & 34 & 12.4 \\
\hline Not working & 241 & 87.6 \\
\hline \multicolumn{3}{|l|}{ Living with parents } \\
\hline Yes & 122 & 44.4 \\
\hline No & 153 & 55.6 \\
\hline \multicolumn{3}{|l|}{ Course } \\
\hline Nursing & 64 & 23.3 \\
\hline Pharmacy & 31 & 11.3 \\
\hline Physiotherapy & 96 & 34.9 \\
\hline Dentistry & 63 & 22.9 \\
\hline Psychology & 21 & 7.6 \\
\hline Total & 275 & 100.0 \\
\hline
\end{tabular}

Table 2 presents the list of occupational diseases considered as occupational by the participants of this study, among which the most commonly cited were influenza (65.5\%) and hepatitis B (58.5\%).

According to Table 3, 29.5\% of students reported having attended to patients with infectious diseases, especially with the AIDS virus (45.7\%) and hepatitis (38.3\%). Contact with body fluids that could be contaminated or accidental exposure was highlighted by $12.7 \%$ of respondents, which occurred through skin-piercing instruments (34.3\%) and contact with saliva (31.4\%).

Table 2. Self-report of prevalence of diseases considered as occupational by the interviewees.

\begin{tabular}{lcccc}
\hline \multirow{2}{*}{ Variable } & \multicolumn{2}{c}{ Yes } & \multicolumn{2}{c}{ No } \\
\cline { 2 - 5 } & $\mathbf{n}$ & $\%$ & $\mathrm{n}$ & $\%$ \\
\hline - Influenza & 180 & 65.5 & 95 & 34.5 \\
- Hepatitis B & 161 & 58.5 & 114 & 41.5 \\
- Tetanus & 130 & 47.3 & 145 & 52.7 \\
- Measles & 117 & 42.5 & 158 & 57.5 \\
- Rubella & 112 & 40.7 & 163 & 59.3 \\
- Hepatitis A & 107 & 38.9 & 168 & 61.1 \\
- Mumps & 87 & 31.6 & 188 & 68.4 \\
- Chickenpox & 54 & 19.6 & 221 & 80.4 \\
- Pertussis & 38 & 13.8 & 237 & 86.2 \\
- Diphtheria & 31 & 11.3 & 244 & 88.7 \\
\hline
\end{tabular}

Note: The percentage calculations were obtained from the total number of 275 respondents.

Table 3. Distribution of respondents according to their views on occupational infections; contact with patients with infectious disease and body fluids and the type of exposure to body fluids.

\begin{tabular}{lcc}
\hline \multicolumn{1}{c}{ Variable } & $\mathrm{n}$ & $\%$ \\
\hline $\begin{array}{l}\text { Have you ever met a patient with an } \\
\text { infectious disease? }\end{array}$ & & \\
Yes & 81 & 29.5 \\
No & 194 & 70.5 \\
Total & 275 & 100.0 \\
Which diseases? & & \\
Aids & 37 & 45.7 \\
Hepatitis & 31 & 38.3 \\
Influenza & 17 & 21.0 \\
Tuberculosis & 15 & 18.5 \\
Leprosy & 4 & 4.9 \\
Measles & 1 & 1.2 \\
Basis* & 81 & \\
Have you had contact with body fluids & & \\
that could be contaminated, or have gone & & \\
through some accidental exposure? & & \\
Yes & 35 & 12.7 \\
No & 240 & 87.3 \\
Total & 275 & 100.0 \\
What kind of exposure? & & \\
Accident with drill-cutting tool & 12 & 34.3 \\
Contact with saliva & 11 & 31.4 \\
Contact with blood without drilling & 5 & 14.3 \\
Pulmonary secretions & 4 & 11.4 \\
Other secretions & 3 & 8.6 \\
Total & 35 & 100.0 \\
\hline
\end{tabular}

* Where a single student has reported more than one disease, it is recorded as the basis for calculation of the percentages and not as the total.

Most students $(82.2 \%)$ reported that their vaccination tables were incomplete due to lack of time $(30.3 \%)$ and 
forgetfulness $(22.5 \%)$. There was a significant difference between the means of contamination $(p=0.01)$ reported by students of the different courses (Table 4).
In Table 5 there was no association between the variables analyzed and vaccination table of students surveyed.

Table 4. Association of vaccination profile, concepts of occupational risk and knowledge about ways of contamination according to the health field.

\begin{tabular}{|c|c|c|c|c|c|c|c|c|c|c|c|c|c|}
\hline \multirow{3}{*}{ Variable } & \multicolumn{10}{|c|}{ Health field } & \multirow{2}{*}{\multicolumn{2}{|c|}{ Group total }} & \multirow{3}{*}{$P$ value } \\
\hline & \multicolumn{2}{|c|}{ Nursing } & \multicolumn{2}{|c|}{ Pharmacy } & \multicolumn{2}{|c|}{ Physical therapy } & \multicolumn{2}{|c|}{ Dentistry } & \multicolumn{2}{|c|}{ Psychology } & & & \\
\hline & $\mathrm{n}$ & $\%$ & $\mathrm{n}$ & $\%$ & $n$ & $\%$ & $\mathrm{n}$ & $\%$ & $\mathrm{n}$ & $\%$ & $\mathrm{n}$ & $\%$ & \\
\hline \multicolumn{14}{|c|}{ Vaccination coverage } \\
\hline Incomplete & 45 & 70.3 & 28 & 90.3 & 82 & 85.4 & 54 & 85.7 & 17 & 80.9 & 226 & 100.0 & \multirow{3}{*}{$0.06^{* *}$} \\
\hline Complete & 19 & 29.7 & 3 & 9.7 & 14 & 14.6 & 9 & 14.3 & 4 & 19.1 & 49 & 100.0 & \\
\hline Total & 64 & 100.0 & 31 & 100.0 & 96 & 100.0 & 63 & 100.0 & 21 & 100.0 & 275 & 100.0 & \\
\hline \multicolumn{14}{|l|}{ Cause } \\
\hline Forgot & 3 & 23.0 & 3 & 27.2 & 7 & 18.9 & 6 & 28.6 & 1 & 12.5 & 20 & 100.0 & \multirow{5}{*}{$0.33^{* *}$} \\
\hline Lack of time & 5 & 38.4 & 3 & 27.2 & 12 & 32.5 & 3 & 14.3 & 4 & 50.0 & 27 & 100.0 & \\
\hline Negligence & 3 & 23.0 & 2 & 18.3 & 9 & 24.3 & 3 & 14.3 & 1 & 12.5 & 18 & 100.0 & \\
\hline Others & 2 & 15.6 & 2 & 18.3 & 9 & 24.3 & 9 & 42.8 & 2 & 25.0 & 24 & 100.0 & \\
\hline Total & 13 & 100.0 & 11 & 100.0 & 37 & 100.0 & 21 & 100.0 & 8 & 9.0 & 89 & 100.0 & \\
\hline \multicolumn{14}{|c|}{$\begin{array}{l}\text { Knowing means of } \\
\text { contamination }\end{array}$} \\
\hline Yes & 47 & 73.4 & 26 & 83.9 & 67 & 69.8 & 54 & 85.7 & 11 & 52.4 & 205 & 100.0 & \multirow{3}{*}{$0.01^{*}$} \\
\hline No & 17 & 26.6 & 5 & 16.1 & 29 & 30.2 & 9 & 14.3 & 10 & 47.6 & 70 & 100.0 & \\
\hline Total & 64 & 100.0 & 31 & 100.0 & 96 & 100.0 & 63 & 100.0 & 21 & 100.0 & 275 & 100.0 & \\
\hline
\end{tabular}

${ }^{*}$ Chi-square test; ${ }^{* *}$ Fisher's exact test.

Table 5. Assessment on the vaccination table according to age range, sex, marital status, occupation, household situation and health field.

\begin{tabular}{|c|c|c|c|c|c|c|c|c|}
\hline \multirow{3}{*}{ Variable } & \multicolumn{4}{|c|}{ Vaccination coverage } & \multirow{2}{*}{\multicolumn{2}{|c|}{ Total }} & \multirow{3}{*}{$P$ value } & \multirow{3}{*}{ OR (Cl 95\%) } \\
\hline & \multicolumn{2}{|c|}{ Incomplete } & \multicolumn{2}{|c|}{ Complete } & & & & \\
\hline & $\mathrm{n}$ & $\%$ & $\mathrm{n}$ & $\%$ & $\mathrm{n}$ & $\%$ & & \\
\hline \multicolumn{9}{|l|}{ Age range } \\
\hline 18 to 21 years & 76 & 85.4 & 13 & 14.6 & 89 & 100.0 & \multirow{3}{*}{$0.39 *$} & 1.0 \\
\hline 22 to 23 years & 80 & 80.8 & 19 & 19.2 & 99 & 100.0 & & $0.6(0.1$ to 3.0 \\
\hline 24 to 57 years & 70 & 80.5 & 17 & 19.5 & 87 & 100.0 & & $0.5(0.1$ to 2.8 \\
\hline \multicolumn{9}{|l|}{ Gender } \\
\hline Male & 75 & 79.8 & 19 & 20.2 & 94 & 100.0 & \multirow{2}{*}{$0.45^{*}$} & 1.0 \\
\hline Female & 151 & 83.4 & 30 & 16.6 & 181 & 100.0 & & 0.7 (0.4 to 1.4 \\
\hline \multicolumn{9}{|l|}{ Marital status } \\
\hline Single & 209 & 82.3 & 45 & 17.7 & 254 & 100.0 & \multirow{2}{*}{$0.87^{* *}$} & $1.0(0.3$ to 3.4 \\
\hline Married & 17 & 81.0 & 4 & 19.0 & 21 & 100.0 & & 1.0 \\
\hline \multicolumn{9}{|c|}{ Occupational status } \\
\hline Working (out) & 26 & 76.5 & 8 & 23.5 & 34 & 100.0 & \multirow{2}{*}{$0.35^{*}$} & 1.0 \\
\hline Not working & 200 & 83.0 & 41 & 17.0 & 241 & 100.0 & & 0.6 (0.2 to 1.5 \\
\hline \multicolumn{9}{|l|}{ Living with parents } \\
\hline Yes & 100 & 82.0 & 22 & 18.0 & 122 & 100.0 & \multirow{2}{*}{$0.93^{*}$} & 1.0 \\
\hline No & 126 & 82.4 & 27 & 17.6 & 153 & 100.0 & & 0.8 (0.4 to 1.6 \\
\hline \multicolumn{9}{|l|}{ Health field } \\
\hline Nursing & 45 & 70.3 & 19 & 29.7 & 64 & 100.0 & & 1.0 \\
\hline Pharmacy & 28 & 90.3 & 3 & 9.7 & 31 & 100.0 & \multirow{5}{*}{$0.52^{*}$} & 0 \\
\hline Physiotherapy & 82 & 85.4 & 14 & 14.6 & 96 & 100.0 & & $0.6(0.1$ to 2.7$)$ \\
\hline Dentistry & 54 & 85.7 & 9 & 14.3 & 63 & 100.0 & & 0.2 (0.1 to 2.2 \\
\hline Psychology & 17 & 81.0 & 4 & 19.0 & 21 & 100.0 & & 0 \\
\hline Total & 226 & 82.2 & 49 & 17.8 & 275 & 100.0 & & \\
\hline
\end{tabular}

* Chi-square test; ${ }^{* *}$ Fisher's exact test. 


\section{Discussion}

The profile of respondents is predominantly young, female and single, who reported no other work activities beyond those academically performed in their courses and not living with their parents (Table 1). This aspect reflects the city of Campina Grande which is known as a "college town", since it has two public universities, twelve private and one Federal Institute. It is usual students from other places to come and live in the city to study (7). Considering the growing concern about the prevention of occupational diseases, few studies address the issue, especially among college students $(2,9,10)$.

The most often reported occupational disease by students was influenza (65.5\%) followed by hepatitis B (58.5\%), corroborating another Brazilian study (1). Indeed influenza is an illness that causes concern, not only by the risk to health professionals but also due to its transmission in hospitalized patients with low immunity (11). Hepatitis B, however, is the occupational disease of greatest risk to health professionals, being the major cause of acute and chronic liver disease, cirrhosis and hepatocellular carcinoma (15-17). Varicella (19.6\%), whooping cough (13.8\%) and diphtheria $(11.8 \%)$ were rarely mentioned (Table 2 ). However, these conditions are considered as high risk in some situations with the vaccination considered as priority (12), such as pertussis, especially in groups of professionals working on neonatology, pediatrics, and patients with chronic-respiratory disesases (13). AIDS has not been cited, reflecting the lack of information from these students, or even denial about the problem that is still a stigma (14). However, the hepatitis B and $\mathrm{C}$ viruses and the human immunodeficiency virus (HIV) are an important infectious agent in occupational infections occurring in health services (15).

The report of attendance experience on patients with infectious diseases was made by $29.5 \%$ of students, who reported AIDS and hepatitis (Table 3) among health problems. AIDS still has no vaccine to prevent its infection requiring the rules of Standard Precautions (personal protective equipment) to be adopted in full, regardless of the definite or presumed diagnosis of this condition (16). For hepatitis, it is necessary not only to use personal protective equipment but also to have the immunization (17).

Exposure to potentially contaminated body fluids or the occurrence of accidental exposure were highlighted by $12.7 \%$ respondents and among the vehicles of exposure being highlighted were accidents with skin-piercing instruments $(34.3 \%)$ and contact with saliva $(31.4 \%)$ (Table 3). The lack of experience of students increases the occupational risk, justifying the immunization of this group as early as possible (18). Most students (88.2\%) presented an incomplete vaccination table, there being no significant difference between courses $(P=0.06)$ (Table 4). Overall, the deficiency in vaccination coverage among students has been reported in the literature $(9,19)$. It is emphasized that there are no specific rules guiding the Higher Education Institutions concerning the vaccination coverage of students with training in health area, it being perceived, in fact, that there are difficulties in maintaining this control.

The main reasons highlighted by students who did not take all doses of vaccines were the lack of time $(27 \%)$ and forgetfulness $(22.2 \%)$, there being no significant difference between courses $(P=0.33)$ (Table 4$)$. These reasons are also cited in other studies to justify the vaccine table failure as well as the fear by side effects, lack of vaccines and doubts about its effectiveness $(20,21)$.

With regard to the means of contamination of occupational infections, most students $(74.5 \%)$ claimed to know these vehicles $(P=0.01)$. Dentistry Students had a higher percentage of positive responses $(85.7 \%)$, followed by Pharmacy $(83.9 \%)$ and Nursing $(73.4 \%)$ (Table 4$)$. The use of skin-piercing instruments and the increased contact with body fluids probably influenced this result (17).

No association was observed between age, gender, marital status, occupation status, residence with parents, type of course and immunization coverage (Table 5). This result emphasizes specific deepening through new studies in courses and different communities. Studies using the qualitative methodology would greatly contribute to the deepening of the subject and provide guidelines for building more effective vaccination programs directed at this population.

This study has limitations that should be recognized. Data was collected through personal report, the vaccination card was not required. However, this method was also used in other studies $(2,5,17)$. In the institution surveyed, not all the courses in the health area were covered which prevented the completion of a survey covering a larger number of health areas. Nevertheless, it is believed that the results would not change depending on the course, since when the five courses were compared there was no statistically significant difference.

The features observed in this study demonstrate that there are still gaps in the knowledge of students attending the health area courses about infectious diseases, occupational risk and immune-preventable diseases. Moreover, vaccination coverage is still sporadic, this being a problem similar to other national $(1,2,5)$ and international $(9,10)$ institutions. Some considerations can be made from these results. The discussion about occupational risk and immunization must be conducted in depth by the Health Care and Educational institutions, requiring greater focus on the subject throughout the course. Thus, disciplines on biosafety and occupational risk should be incorporated into the curriculum, with a different methodology and a practical-theoretical approach aimed at strengthening the knowledge and awareness of the subject importance $(22,23)$. The vigilance about infection control should also be adopted by those responsible for curriculum components taught in clinical activities. With this perspective, it is warned that simple guidance for the students about the need for immunization is not enough (24), and that mandatory vaccination (21), awareness and motivation to participate in vaccination programs and ease of access (25), accompanied by continuous educational campaigns can contribute to an increase in immunization coverage. 


\section{Conclusion}

The knowledge of occupational diseases and vaccination coverage was poor, reflecting the need for motivational policies, through activities for clarification and expansion of vaccination coverage.

1. Dinelli MI, Moreira TN, Paulino ER, Da Rocha MC, Graciani FB, De Moraes-Pinto MI. Immune status and risk perception of acquisition of vaccine preventable diseases among health care workers. Am J Infect Control 2009;37:858-60.

2. Chehuen Neto JA, Sirimarc MT, Leite ICG, Gonçalves MPC, Delgado AA, Camilo GB et al. Undergraduates' Immunization Status at the UFJF Medical School. Rev Bras Educ Med 2010;34: 270-77.

3. Brasil. Ministério do Trabalho e Emprego. Gabinete do Ministro. Portaria N. ${ }^{\circ} 485$, de 11 de Novembro de 2005. Norma Regulamentadora n. ${ }^{\circ} 32$ (Segurança e Saúde no Trabalho em Estabelecimentos de Saúde). [Accessed on 2011 Jan 27]. Available at http://www.mte. gov.br/legislacao/portarias/2005/p_20051111_485.pdf

4. Brasil. Ministério da Saúde. Fundação Nacional da Saúde. Manual dos Centros de Referência de Imunobiológicos Especiais. Brasília. 2001.

5. Araujo TME, Paz EPA, Griep RH. Vacinal covering of the professionals of the specialization course in family health of Piaui. Esc Anna Nery R Enferm 2006;10:95-100.

6. Noula M, Raftopoulos V, Gesouli E, Tsaprounis T, Deltsidou A. Greek nursing students' immunization coverage: data from central continental Greece. Nurs Health Sci 2008; 10:169-74.

7. Instituto Brasileiro de Geografia e Estatística. Cidades@. [Accessed on 2011 Jan 27]. Available at http://www.ibge.gov.br/cidadesat/default.php.

8. Frankfort-Nachimias C, Nachimias D. Research methods in the social sciences. London: Edward Arnold; 1992.

9. Trevisan A, Bruno A, Mongillo M, Morandin M, Pantaleoni A, Borella-Venturini M et al. Prevalence of markers for hepatitis $B$ virus and vaccination compliance among medical school students in Italy. Infect Control Hosp Epidemiol 2008;29:1 189-91.

10. Pavlopoulou ID, Daikos GL, Tzivaras A, Bozas E, Kosmidis C., Tsoumakas C, et al. Medical and nursing students with suboptimal protective immunity against vaccine-preventable diseases. Infect Control Hosp Epidemiol 2009;30:1006-11.

11. Hollmeyer HG, Hayden F, Poland G, Buchholz U. Influenza vaccination of health care workers in hospitals - A review of studies on attitudes and predictors. Vaccine 2009;27:3935-44

12. Zimmerman RK, Middleton DB. Vaccines for persons at high risk due to medical conditions, occupation, environment, or lifestyle, 2005. J Fam Pract 2005;54:27-36.

13. Advisory Committee on Immunization Practices. General Recommendations on Immunizations. MMWR 2002;51:1-36.

14. Senna MIB, Guimarães MDC, Pordeus IA. Factors associated with dentists' willingness to treat HIV/AIDS patients in the National Health System in Belo Horizonte, Minas Gerais, Brazil. Cad Saúde Pública 2005;21:217-25.

15. Cleveland JL, Cardo DM. Occupational exposures to human immunodeficiency virus, hepatitis $B$ virus, and hepatitis $C$ virus: risk, prevention, and management. Dent Clin North Am 2003;47:681-96.

16. Rissi MRR, Machado AA, Figueiredo MAC. Health care workers and AIDS: a differential study of beliefs and affects associated with accidental exposure to blood. Cad. Saúde Pública 2005;21:283-91.

17. Resende VLS, Abreu MHG, Paiva SM, Teixeira R, Pordeus IA. Concerns regarding hepatitis $B$ vaccination and post-vaccination test among Brazilian dentists. Virol J 2010;7:154-59.

18. American Academy of Pediatrics. Pickering LK. Red Book: Report of the Committee on Infectious Diseases. Elk Grove Village: American Academy of Pediatrics; 2000.

19. Hesham R, Cheong JY, Hasni JM. Knowledge, attitude and vaccination status of varicella among students of Universiti Kebangsaan Malaysia (UKM). Med J Malaysia 2009;64: 118-23.

20. Murray SB, Skull SA. Poor health care worker vaccination coverage and knowledge of vaccination recommendations in a tertiary Australian hospital. Aust N Z J Public Health 2002;26:65-8.

21. Loulergue P, Moulin F, Vidal-Trecan G, Absi Z, Demontpion C, Menager C et al. Knowledge, attitudes and vaccination coverage of healthcare workers regarding occupational vaccinations. Vaccine $2009 ; 24: 4240-3$. 
22. Ardenghi DM, Roth WM, Ardenghi LP. Responsibility in dental praxis: an activity theoretical perspective. JWL 2007;19:240-55.

23. Machado-Carvalhais HP, Ramos-Jorge ML, Auad SM, Martins KHPM, Paiva SM, Pordeus IA. Occupational exposure to potentially infectious biological material in a dental teaching environment. J Dent Educ 2008;72:1201-08.

24. Gir E, Caffer Netto J, Malaguti SE, Canini SRMS, Hayashida M, Machado AA. Accidents with biological material and immunization against Hepatitis $B$ among students from the health area. Rev Latino-am Enfermagem 2008;16:401-6.

25. Machado-Carvalhais HP, Ramos-Jorge ML, Auad SM, Martins KHPM, Martins SP, Pordeus I. Management of occupational bloodborne exposure in a dental teaching environment. J Dent Educ 2007;71:1348-55. 